e-ISSN: 2623-0089

Website :

jurnal.umj.ac.id/index.php/baskara

Email : baskara@umj.ac.id

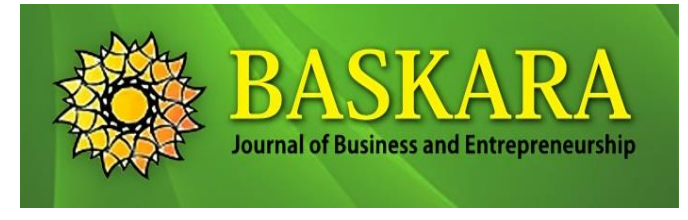

\title{
Entrepreneurial Knowledge on Entrepreneurial Intention: The Mediating of Perceived Desirability and Perceived Feasibility
}

\author{
Yekti Sulistyorini' ${ }^{1}$ Budi Santoso ${ }^{2}$ \\ Faculty of Economic Education Pascasarjana, Indonesia University of Education \\ Jl. Dr. Setiabudi No.229 Ledeng Cidadap Bandung 40154 \\ E-mail: ${ }^{1}$ yekti.sulistyorini@upi.edu ${ }^{2}$ budisantoso@upi.edu
}

Received: 02032021

Revised: 07042021

Approved: 08042021

\begin{abstract}
Entrepreneurship plays an important role in the creation and growth of business as well as the growth and prosperity of the region and the country. The importance of entrepreneurship in job creation and economic development is recognized worldwide. This research is motivated by the low entrepreneurial intention of Vocational High School students which is also have an impact on unemployment. This study aims to determine and analyse the mediating effect of perceived desirability and perceived feasibility on the effect of entrepreneurial knowledge on entrepreneurial intention. The method used in study is an explanatory survey research with data collection techniques through a questionnaire and observation. The population of this study were students of PGRI Bandung Vocational High School class XI and XII academic year 2019/2020 as many as 305 students and sample of this research is 176 students. The results show that: 1) entrepreneurial knowledge has a significant effect on entrepreneurial Intention 2) perceived desirability mediates the effect of entrepreneurial knowledge on entrepreneurial intention 3) perceived feasibility mediates the effect of entrepreneurial knowledge on entrepreneurial intention.
\end{abstract}

Keywords: Entrepreneurial Knowledge, Entrepreneurial Intention, Perceived Desirability

\section{INTRODUCTION}

Entrepreneurship plays an important role in the creation and growth of business as well as the growth and prosperity of the region and the country (Hisrich et al., 2017). The entrepreneurial climate stimulates innovation, fosters economic transactions and can encourage the creation of various jobs (Yulianto, 2016). The role of entrepreneurship is not only as a driving force for the community's economy, but also as a driver for social change to improve the quality of human life (Darmadji, 2012). Many entrepreneurs produce the products that make human life easier and more comfortable so that humans become more productive, communicate easier and find out more about what is happening around them (Suranto, 2011).

Indonesia needs at least 4 million new entrepreneurs to help strengthen the economic structure. Meanwhile, the current entrepreneurial ratio in the country is still around 3.1 percent of the total population. This ratio is still far below neighbouring countries such as Malaysia, which is already at the 5 percent level and Singapore which has reached the 7 percent level (Ministry of Industry, 2018). For this reason, the government needs to encourage to increase the number of entrepreneurs so that the economy in Indonesia can develop. The number of qualified entrepreneurs in a country is determined by the number of 
Baskara : Journal of Business and Entrepreneurship

Volume 3 No. 2 April 2021

students who intend to become entrepreneurs (Linan \& Chen, 2009).

Intention is considered as the best predictor to predict a person's interest in becoming an entrepreneur (Krueger et al., 2000). Intention is defined as a state of mind that directs one's attention (experiences and actions) towards certain objects and goals or paths (means) to achieve something (Bird, 2014). In simple terms, intention is also defined as a sense of preference and a sense of attachment to something or activity, without being asked (Slameto, 2010). Meanwhile entrepreneurship is a process that integrates opportunities, resources and people (Timmons and Spinelli, 2009). Thus the intention of entrepreneurship can be interpreted as the tendency of the heart in a person to be interested in creating a business which then organizes, manages, takes risks and develops the business he creates (Suryana, 2006).

The importance of entrepreneurship in job creation and economic development is recognized worldwide (Malebana \& Swanepoel, 2019). Based on the Global Entrepreneurship Index (GEI) 2019 report, Indonesia is ranked 75th out of 137 countries. This data shows that Indonesia still has a low level of entrepreneurship compared to other countries (GEI, 2019).

Unemployment occurs because the ratio between the number of job opportunities offers is not proportional to the number of graduates or the supply of new workers at all levels of education (Sumadi \& Sulistyawati, 2017). Judging from the highest education level completed in February 2017 to February 2019, Vocational High Schools (SMK) contributed the highest unemployment rate compared to SD, SMP, SMA, Diploma and University education levels, namely 8.63 percent to 9.27 percent (BPS, 2019).

The causes of vocational unemployment are the imbalance between expectations for work and limited work capacity, lack of knowledge, skills and creativity in work and lack of motivation and courage to become entrepreneurs (Widiyarini, 2018). Low entrepreneurial intentions also have an impact on unemployment (Fadli et al., 2020; Meswandi, 2018; Tulenan, 2018). In general, the younger generation is more interested in becoming employees than in doing business independently (Niode, 2007). The number of unemployment and poverty can be reduced by having the courage to open new businesses or entrepreneurship (Melyana, Rusdarti \& Pujiati, 2015). In other words, the problem of unemployment in Indonesia can be reduced by increasing the number of entrepreneurs (Kurjono, Asep, 2020).

Vocational High Schools (SMK) have a large enough opportunity to participate in building an economic system by taking advantage of youth development stages and educating students to be interested in becoming entrepreneurs. Therefore, SMK must prepare graduates who are ready to become entrepreneurs and the government recommends SMK graduates to become entrepreneurs in order to support the creation of creative people in the development of creative industries (Cucu, 2020).

The two main theories used as the basis for researchers to study entrepreneurial intentions are the Entrepreneurial Event Model (Shapero and Sokol, 1982) and The Theory of Planed Behavior (Ajzen, 1991). According to the Entrepreneurial Event theory, entrepreneurial intention is a function of the desire that is felt, the perceived feasibility and the tendency to act (Fadli et al., 2020). Meanwhile, the idea of entrepreneurial intentions conceptualized by Azjen (1991) argues that a person's intention to do something can be seen from attitudes, subjective norms, and perceived behavioral control (Ferreira et al., 2017)) which is known as theory of planned behavior. Then Linan (2004) by adding elements of entrepreneurial knowledge obtained 
through education into the integration of the two models (Linan, 2004).

Linan (2004) proposed that entrepreneurship education to an individual had to strengthen the participant's intention to become an entrepreneur. He developed the concept of entrepreneurial intentionbased models by integrated two theories of planned behavior by Ajzen (1991) and theory of entrepreneurial event by Shapero and Sokol (1982) by adding the element of entrepreneurial knowledge, acquired through education as shown in Figure 1.

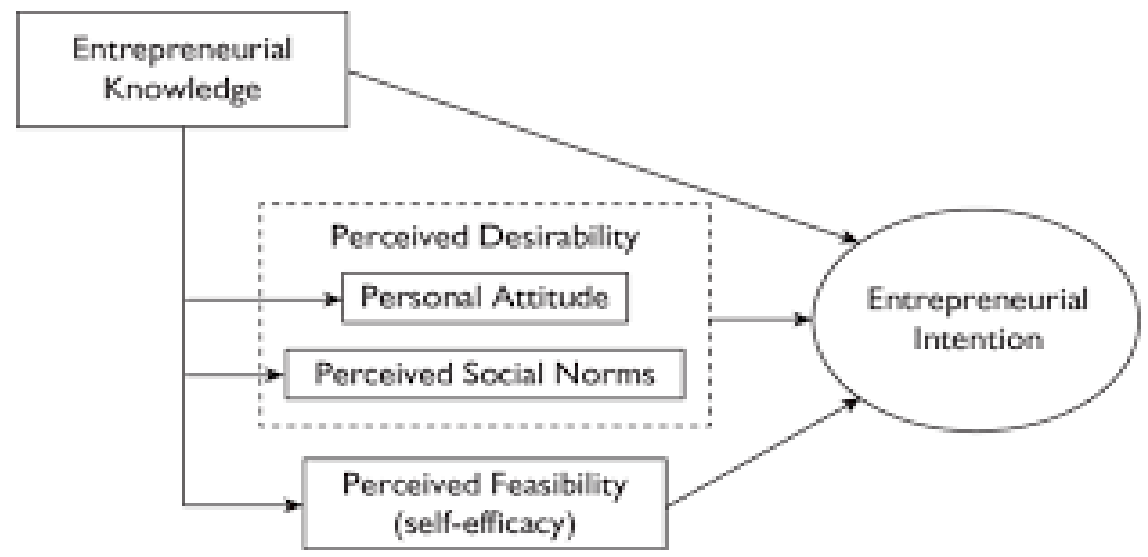

Figure 1. Research Model (Linan, 2004)

The increasing number of entrepreneurs cannot be separated from the role of education (Fadli et al., 2020). Knowledge of entrepreneurship will form a tendency to open new businesses in the future (Darmanto, 2013). According to entrepreneurial human capital (EHC) theory, individuals who have entrepreneurial knowledge tend to become entrepreneurs (Ni \& Ye, 2018). An entrepreneur will not be successful if he does not have the knowledge, ability, and will (Suryana, 2006). Entrepreneurship education can strengthen a person's intention to become an entrepreneur (Linan, 2004). Entrepreneurial knowledge refers to the level of individual knowledge required to start and run a business which includes knowledge of entrepreneurial opportunity recognition and exploitation and knowledge in finance. aspects of starting and running the business as financial management, marketing, production, and human resource management (Roxas et al., 2009). Therefore, it is necessary to have entrepreneurship education in the curriculum at every level of education (Kurjono, Asep, 2020).

Individuals who have entrepreneurial knowledge factors will be able to develop positive perceptions of entrepreneurial feasibility that give birth to entrepreneurial actions (Darmanto, 2013; Wafiatun et al., 2017). Greater knowledge of the entrepreneurial environment will certainly contribute to a more realistic perception of entrepreneurship and directly provide a greater awareness of the existence of professional choices and desires that serve as the intention to become a more credible entrepreneur.

\section{Entrepreneurial Intention}

Entrepreneurial intention generally refers how likely an individual would set up a business (Linaaan, 2004). Entrepreneurial intention can be interpreted as the tendency of the heart in a person to be interested in creating a business which then organizes, manages, takes risks and develops the 
business he creates (Suryana, 2006). Entrepreneurial intention can be defined as a state of mind that directs and guides individual actions towards the development and implementation of new business concepts.

\section{Entrepreneurial Knowledge}

Entrepreneurial knowledge refers to the level of individual knowledge required to start and run a business that includes knowledge of business opportunities, financial management knowledge, marketing, production, and human resource management knowledge (Roxas et al., 2009). Entrepreneurial knowledge is defined as a person's understanding of entrepreneurship with positive, creative, and innovative characters in developing business opportunities to become business opportunities that benefit him and society or consumers (Kuntowicaksono, 2012).

\section{Perceived Desirability}

Perceived desirability refers to the degree to which a person feels an attraction towards a given behaviour (to become an entrepreneur (Linan, 2004; Degeorge \& Fayolle, 2011). Shapero \& Sokol (1982) argues that someone who has a high perceived desire will feel enthusiastic about starting a new business and become a big advantage in an on-going business (Almqvist \& Björnberg, 2010). Perceived desirability is felt has in common with attitudes towards behavior and subjective norms (Kurniawan, 2019). The perceived social norms are considered as an additional aspect to strengthen the performance of attitude and behaviour coming from outside the individual (Buana et al., 2017).

\section{Perceived Feasibility}

The perceived feasibility reflects the level of ability and skills felt by the individual which enables him to face potential challenges (Almqvist \& Björnberg, 2010). Perceived feasibility has in common with perceived behavioral control or self-efficacy (Kurniawan, 2019; Hisrich et al., 2017). Self-efficacy significantly influenced entrepreneurial behavior and was a key tool in entrepreneurship education to improve students' entrepreneurial intentions (Fayolle \& Gailly, 2015). Individuals will have stronger intentions to act when taking action is deemed appropriate and pleasurable. The higher the feasibility and the perceived desire, the stronger the intention to act entrepreneurially (Hisrich et al., 2017).

Previous research has shown that perceived desirability and perceived feasibility have a positive and significant effect on entrepreneurial intentions. (Guerrero et al., 2008; Giagtzi, 2013; Dissanayake, 2014; Asunka, 2016; Hattab, 2014; Kurniawan, 2019).

\section{RESEARCH METHODS}

The method used in this research is descriptive verification method with quantitative survey design. The research population is the students of SMK PGRI Bandung. The sample size of the study used the Isaac Michael formula (Sugiyono, 2004). From the total population, the sample size was 176 respondents. This study consisted of 4 variables entrepreneurial intention (Y) as an endogenous variable referring to (Van Gelderen et al., 2008; Vemmy, 2013 ; Handaru et al., 2014) consisting of 3 indicators; preference (3 item), desire (2 items) and plans (3 items). Entrepreneurial knowledge (X1), referring to (Roxas et al., 2009 ; Kurjono, 2017) consists of 4 indicator; basic knowledge of entrepreneurship

(3 items), knowledge of business opportunities (2 items), knowledge of business planning (1 item) and knowledge of business aspects (4 items). Perceived desirability (M1) refers to (Krueger et al., 2000; Linan, 2004; Shook \& Bratianu, 2010; Dissanayake, 2014 Panwala et al., 2017) consist of 2 indicators; 
personal attitude (4 items) and perceived social norms (3 items). Perceived feasibility (M2) refers to (Krueger et al 1994, Guerrero et al., 2008 ; Kurjono, 2017) consisting of 1 indicator, : entrepreneurial self efficacy.

\section{RESULTS AND DISCUSSION}

\section{Direct Effects of the Entrepreneurial Knowledge on Entrepreneurial Intentions}

The test results show partially the direct effect of entrepreneurial knowledge (EK) on entrepreneurial intention (EI) (direct effect of $\mathrm{X}$ on $\mathrm{Y}=\mathrm{c}^{\prime}$ ) shows the effect coefficient of $c^{\prime}=0.354, t=4,630$, $p$ value $=0,000$. The results of this test indicate that basically entrepreneurial knowledge has a positive effect on entrepreneurial intentions and is also statistically significant ( $\mathrm{p}$-value $<0.05$ ).

The first hypothesis which states that entrepreneurial knowledge has a direct effect on entrepreneurial intentions, then the first hypothesis can be accepted. The results of the study indicate that entrepreneurial knowledge has a direct and significant effect on students' entrepreneurial intentions.

\section{Mediating Effect of Perceived Desirability on the Effect of Entrepreneurial Knowledge on Entrepreneurial Intentions}

The result show partially entrepreneurial knowledge (EK) has a positive effect on perceived desirability (PD) with a coefficient of a1 $=0.495, \mathrm{t}=$ 17.077, $\mathrm{p}$-value $=0.000$. This shows that the positive influence of entrepreneurial knowledge (EK) on internal perceived desirability (PD) is statistically significant (P-value <0.05).
The same result also occurs in the entrepreneurial intention (EI) model which is positively influenced by perceived desirability (PD). This shows that the effect of perceived desirability (PD) on entrepreneurial intention (EI) is positive and statistically significant.

Based on the explanation above, then to answer the second hypothesis, the statistical test is followed by testing to determine the indirect effect of entrepreneurial knowledge (EK) on entrepreneurial intention (EI) through perceived desirability (PD) (indirect effect of $\mathrm{X}$ on $\mathrm{Y}$ via $\mathrm{M} 1=\mathrm{a} 1 \mathrm{~b} 1)$ which is estimated as a1 b1 $=0.495(0.204)=0.100$. The effect of the indirect effect $(\mathrm{EK} \rightarrow \mathrm{PD}$ $\rightarrow \mathrm{EI})$ is 0.100 which is interpreted as significantly positive. The results show that perceived desirability mediates the effect of entrepreneurial knowledge on entrepreneurial intentions.

Mediating Effect of Perceived Feasibility on the Effect of Entrepreneurship Knowledge on Entrepreneurial Intentions

The results show partially that perceived feasibility (PF) is positively influenced by entrepreneurial knowledge (EK) with a coefficient of $\mathrm{a} 2=0.428, \mathrm{t}=$ $18,117, \mathrm{P}$-value $=0.000$. This shows that the positive influence of entrepreneurial knowledge $(\mathrm{EK})$ on perceived feasibility $(\mathrm{PF})$ is statistically significant ( $\mathrm{P}$-value $<0.05)$.

The same result also occurs in the entrepreneurial intention (EI) model which is positively influenced by perceived feasibility (PF), this can be seen from the coefficient $\mathrm{b} 2=0.514, \mathrm{t}=3.334, \mathrm{P}$-value $=$ 0.001. This shows that the effect of 
perceived feasibility (PF) on entrepreneurial intention (EI) is positive and statistically significant.

Based on the explanation above, then to answer the third hypothesis, the statistical test is followed by testing to determine the indirect effect of entrepreneurial knowledge (EK) on entrepreneurial intention (EI) through perceived feasibility (PF) (indirect effect of $\mathrm{X}$ on $\mathrm{Y}$ via $\mathrm{M} 2=\mathrm{a} 2 \mathrm{~b} 2)$ which is estimated as a2 $\mathrm{b} 2=0.428(0.514)=0.219$

The effect of the indirect effect $(\mathrm{EK} \rightarrow \mathrm{PF}$ $\rightarrow \mathrm{EI})$ is 0.219 which is interpreted as a significant positive. The results of this test indicate that the perceived feasibility (PF) mediates the effect of entrepreneurial knowledge on entrepreneurial intentions.

\section{The Simultan Effect of Entrepreneurial Knowledge, Perceived Desirability and Perceived Feasibility on Entrepreneurial Intentions}

Based on the results of the first hypothesis test, explaining the direct effect of entrepreneurial knowledge on entrepreneurial intention is accepted. The results showed that the higher the entrepreneurial knowledge one has, the higher the entrepreneurial intention.

Based on the results of the second hypothesis test, it explains that the indirect effect of entrepreneurial knowledge through perceived desirability as a mediating variable on entrepreneurial intention is accepted. The results showed that the higher the attitudes and support from the closest person, the higher the entrepreneurial intention.

The third hypothesis test explains the effect of entrepreneurial knowledge through perceived feasibility as a mediating variable on entrepreneurial intention when it is accepted. The results showed that entrepreneurial intentions were determined by the degree of belief about how confident and able to manage the business when they started a business. Someone who has perceived behavioral control tends to be more resilient control to have confidence to start a business as well as to be confident in managing the business.

The fourth hypothesis test explains that the simultaneous effect of entrepreneurial knowledge, perceived desirability and perceived feasibility on entrepreneurial intentions is accepted.

\section{CONCLUSION}

Based on the analysis, hypothesis testing and discussion that has been described, the following conclusions can be drawn:

1) Entrepreneurial knowledge has a positive and significant effect directly on entrepreneurial intentions. This means that the better their knowledge of entrepreneurship, the better their entrepreneurial intentions.

2) Perceived desirability positively and indirectly mediates the effect of entrepreneurial knowledge on entrepreneurial intentions.

3) Perceived feasibility positively and indirectly mediates the effect of entrepreneurial knowledge on entrepreneurial intentions.

\section{REFERENCES}

Almqvist, A. S., \& Björnberg, A. (2010). Selecting Self-Employment of Economic

Asunka, G. (2016). Meningkatkan Minat Wirausaha Siswa Smk Untuk Mengurangi. Journal of Business 
Management Education, 1(3), 21-26.

Bird, B. (1988). Implementing Entrepreneurial Ideas: The Case for Intention. The Academy of Management Review, 13(3), 442.

Buana, Y., Hidayat, D., Prayogi, B., \& Vendy, V. (2017). The Effect of Entrepreneurship Education on Entrepreneurial Intention of University Students by Adopting Linan Model. Binus Business Review, 8(1), 67.

Darmanto, S. (2013). Pengaruh Perceived Desirability,Perceived Feasibility, Propensity To Act terhadap Intensi Berwirausaha,. Jurnal Ilmiah Dinamika Ekonomi Dan Bisnis, 1(2), 85-98.

Degeorge, J. M., \& Fayolle, A. (2011). The entrepreneurial process trigger: A modelling attempt in the French context. Journal of Small Business and Enterprise Development, 18(2), 251277.

Dissanayake, D. (2014). The Impact of Perceived Desirability and Perceived Feasibility on Entrepreneurial Intention among Undergraduate Students in Sri Lanka: An Extended Model. Kelaniya Journal of Management, 2(1), 39.

Fadli, ., Muchtar, Y. C., \& Qamariah, I. (2020). The Effect of Entrepreneurship Education on Entrepreneurial Intention. 117(Gcbme 2018), 15661569.

Fayolle, A., \& Gailly, B. (2015). The impact of entrepreneurship education on entrepreneurial attitudes and intention: Hysteresis and persistence. Journal of Small Business Management, 53(1), 75-93.
Ferreira, J. J., Fernandes, C. I., \& Ratten, V. (2017). The Influence of Entrepreneurship Education on Entrepreneurial Intentions. 19-34. Giagtzi, Z. (2013). How perceived feasibility and desirability of entrepreneurship influence entrepreneurial intentions: A comparison between southern and northern European countries. Masters Thesis, 1-52.

Global Entrepreneurship Index (GEI) 2019, Retrieved January 182021 from http://thegedi.org

Guerrero, M., Rialp, J., \& Urbano, D. (2008). The impact of desirability and feasibility on entrepreneurial intentions: A structural equation model. International Entrepreneurship and Management Journal, 4(1), 35-50.

Handaru, A. W., Parimita, W., Achmad, A., \& Nandiswara, C. (2014). Mahasiswa Magister Management ( Kajian Empiris Pada Sebuah Universitas Negeri Di Jakarta. Jurnal Universitas Paramadina, 11(2), 1046-1061.

Hattab, H. W. (2014). Impact of Entrepreneurship Education on Entrepreneurial Intentions of University Students in Egypt. Journal of Entrepreneurship, 23(1), 1-18.

Hisrich, R. D., Peters, M. P., \& Shepherd, D. A. (2017). Entreprenurship (10th ed).

Krueger, N. F. J., Reilly, M. D., \& Carsrud, A. L. (2000). Competing Models of Entrepreneurial Intentions. Journal of Business Venturing. Journal of Business Kurjono, Asep, R. (2020). Intensi Berwirausaha Melalui Model. 
Ejournal.Upi.Edu, 19(1), 53-66.

Kurjono.(2017).

Knowledge

Entrepreneurship Contribution and Self Efficacy To Improve Creativity Student. Journal manajerial UPI:. 187-210.

Kurniawan, A. (2019). Keinginan dan Kelayakan yang Dirasakan Memediasi Pengaruh Dukungan Universitas Minat Berwirausaha Menurut teori Intensi Entrepreneurial Even Model dari Shapero \& Sokol minat. 7(1), 97109.

Linan, F., \& Y, C. (2009). Development and Cross-Cultural Application of a Specific Instrument to Measure Entrepreneurial Intentions. Entrepreneurship Theory and Practice, 33(3), 593-617.

Liñán, F. (2004). Intention-based models of entrepreneurship education. Piccola Impresa / Small Business, 2004(3), 11-35.

Malebana, M. J., \& Swanepoel, E. (2019). The relationship between exposure to entrepreneurship education and entrepreneurial self-efficacy. Southern African Business Review, 18(1), 1-26.

Ni, H., \& Ye, Y. (2018). Entrepreneurship Education Matters: Exploring Secondary Vocational School Students' Entrepreneurial Intention in China. Asia-Pacific Education Researcher, 27(5), 409-418.

Niode, I. Y. (2007). Peran Wirausaha Sebagai Alternatif Solusi Mengatasi Masalah Pengangguran. Jurnal Inovasi, 4, 1-10.

Roxas, B. G., Cayoca-Panizales, R., \& De Jesus, R. M. (2009). Entrepreneurial Knowledge and its Effects on
Entrepreneurial Intentions:

Development of a Conceptual Framework. Asia-Pacific Social Science Review, 8(2), 61-77. Shook, C. L., \& Bratianu, C. (2010). Entrepreneurial intent in a transitional economy: An application of the theory of planned behavior to Romanian students. International Entrepreneurship and Management Journal, 6(3), 231-247.

Sumadi, A., \& Sulistyawati, E. (2017). Pengaruh Sikap, Motivasi, Dan Lingkungan Terhadap Niat Berwirausaha. None, 6(2), 254696.

Sutianah, Cucu. (2020). National Character Development and Entrepreneurial Character through the Implementation of the 6 Step Teaching Factory Learning Model (TF-6M). Jakarta: Qiara Media

Tulenan, C. B. J. (2018). the Effects of Entrepreneurship Education and Personality Traits on Entrepreneurial Intention Among Iba Students. Jurnal EMBA: Jurnal Riset Ekonomi, Manajemen, Bisnis Dan Akuntansi, 6(2), 758-767.

Unemployment Rate by Education Level, 2015-2020. Retrieved January, 15, 2021, from http://www. bps.go.id

Utara, U. S. (2003). Universitas Sumatera Utara 4. 4-16.

Van Gelderen, M., Brand, M., Van Praag, M., Bodewes, W., Poutsma, E., \& Van Gils, A. (2008). Explaining entrepreneurial intentions by means of the theory of planned behaviour. Career Development International, 13(6), 538-559. 
Vemmy, C. (2013). Faktor-faktor yang mempengaruhi intensi berwirausaha siswa SMK. Jurnal Pendidikan Vokasi, 2(1), 117-126.

Wafiatun, M., Soepatin, \& Praswati, A. N. (2017). Pengaruh Perceived desirability dan Perceived feasibility Terhadap Entrepreneurial intention. 281-294.

Widiyarini. (2018). Mengurangi Pengangguran Terdidik dengan Meningkatkan Semangat Kewirausahaan Melalui Pelatihan Jasa Laundry. Sosio E-Kons, 10(3), 199206.

Yulianto.E.J. (2016). Global Entrepreneurship Index Interpretation 
Business and Entrepreneurship Incubator Center Universitas Muhammadiyah Jakarta

Baskara : Journal of Business and Entrepreneurship

Volume 3 No. 2 April 2021 